\title{
The use of the steric effect of the carrier molecule in the polymer inclu- sion membranes for the separation of cobalt(II), nickel(II), copper(II), and zinc(II) ions
}

\author{
Elzbieta Radzyminska-Lenarcik ${ }^{1}$, Malgorzata Ulewicz ${ }^{2}$ \\ ${ }^{1}$ UTP University of Science and Technology, Department of Inorganic Chemistry, ul. Seminaryjna 3, 85-326 Bydgoszcz, \\ Poland \\ ${ }^{2}$ Czestochowa University of Technology, Department General Building Engineering and Building Physics, Faculty of Civil \\ Engineering, ul. Akademicka 3, 42-200 Czestochowa, Poland \\ "Corresponding authors: e-mail: elaradz@utp.edu.pl,ulewicz@bud.pcz.czest.pl
}

In this study, palladium-modified nickel foam substrate was applied to examine ethanol oxidation reaction (EOR) in 0.1 The transport of cobalt(II), nickel(II), copper(II), and zinc(II) ions from chloride solutions across polymer inclusion membranes (PIMs), which 1-heptylimidazole (1) or 1-heptyl-2-methylimidazole (2) or 1-heptyl-4-methylimidazole $(\underline{\mathbf{3}})$ as the ion carrier was reported. The steric effect for carriers $\underline{\mathbf{2}}$ and $\underline{\mathbf{3}}$ decreases the transport of all ions except $\mathrm{Cu}(\mathrm{II})$. The initial fluxes of metal ions transport across PIMs with the $\underline{\mathbf{1}}-\underline{\mathbf{2}}$ decrease in the sequence: $\mathrm{Cu}(\mathrm{II})>\mathrm{Zn}$ (II) $>\mathrm{Co}(\mathrm{II})>\mathrm{Ni}$ (II), whereas for 3 they were $\mathrm{Cu}(\mathrm{II})>\mathrm{Zn}$ (II) $>\mathrm{Ni}$ (II) $>\mathrm{Co}$ (II). The highest recovery values were obtained for $\mathrm{Cu}(\mathrm{II})$, this being 99 and $85 \%$ for carrier $\underline{\mathbf{1}}$ and $\underline{\mathbf{2}}$, respectively. In both membranes the degree of deposition of the $\mathrm{Zn}$ (II) ions was comparable. $\mathrm{Zn}$ (II), $\mathrm{Co}$ (II) and $\mathrm{Cd}$ (II) ions, which form complexes with coordination numbers 4 and 6 , are more easily recovered with the use of carriers $\underline{\mathbf{2}}$ and $\underline{\mathbf{3}}$. $\mathrm{Ni}(\mathrm{II})$ ions, which form complexes with coordination number 6 only, practically remain in the feeding phase. PIMs with alkylimidazoles were characterized by non-contact atomic force microscopy.

Keywords: polymer inclusion membrane, separation ions, steric effect, copper(II), cobalt(II), nickel(II), cadmium(II), zinc(II), alkylimidazole.

\section{INTRODUCTION}

The process of metal ions transport through polymer inclusion membranes (PIM) may be considered as a coupled (combined) process of extraction and re-extraction. The reactants which act as extractants in PIM's are carriers of the metal cations. The cations transport and the possibility of their selective separation are determined by the way the cations react with the carriers and by the structure and stability of the complexes being formed ${ }^{1-4}$.

Alkyl derivatives of imidazole are a convenient group of bases of which the complex-forming properties in respect of transition metals may be predicted and programmed in order to differentiate their extraction properties so as to improve the selectivity of recovery of selected metals ${ }^{5-11}$. When used as carriers in PIM's, alkylimidazoles provide selective transport of selected metal ions ${ }^{12-16}$.

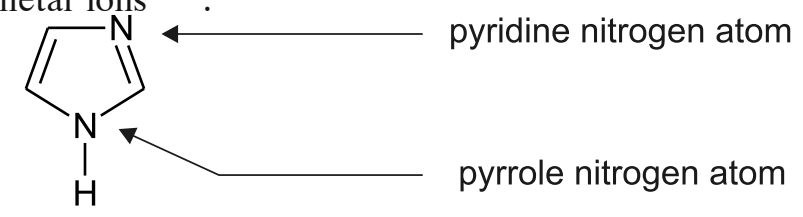

Figure 1. Molecule of imidazole

Although a weaker base than ammonia, imidazole (pKa $=7.12^{17}$ ) (Fig. 1) forms more stable complexes with transition metal cations due to back-donation, therefore, it is classified as a soft base according to the HSAB theory $^{18}$. Its alkalinity and complex stability constants may be somewhat improved by substituting an ever longer alkyl group in position $1^{19}$. On the other hand, when introduced in position 2 or 4, even small alkyl group will increase the alkalinity of a pyridine nitrogen atom by even as much as one order of magnitude but will also reduce the contribution of the $\pi_{M \leftarrow L}$ bond component. When placed in such positions, the groups constitute a steric hindrance making it difficult to form a stable coordination bond with metal cations ${ }^{5,9-11,20-25}$. As a result of the two effects, the 6-coordination (octahedral) complexes with 2 or 4 substituted alkylimidazoles have lower values of their stability constants. The phenomenon is observed especially for those metal cations with a rigid, octahedral structure of their coordination sphere which is hard to deform, for instance $\mathrm{Ni}(\mathrm{II})$.

The steric effect much less hinders the formation of tetrahedral complexes of 1-alkyl-2-methylimidazoles and 1-alkyl-4-methylimidazoles ${ }^{5,9-11,20,21,25}$ with cations which have an ability to change the shape of a coordination polyhedron from an octahedron to a tetrahedron (equations 1,2 ).

$\left[\mathrm{M}\left(\mathrm{H}_{2} \mathrm{O}\right)_{6}\right]^{2+}+\mathrm{nL}+2 \mathrm{~A}^{-} \leftrightarrow\left[\mathrm{M}\left(\mathrm{H}_{2} \mathrm{O}\right)_{6-\mathrm{n}} \mathrm{L}_{\mathrm{n}}\right] \mathrm{A}_{2}+\mathrm{nH}_{2} \mathrm{O}$

$\left[\mathrm{M}\left(\mathrm{H}_{2} \mathrm{O}\right)_{6}\right]^{2+}+\mathrm{nL}+2 \mathrm{~A}^{-} \leftrightarrow\left[\mathrm{M}\left(\mathrm{H}_{2} \mathrm{O}\right)_{4-\mathrm{n}} \mathrm{L}_{\mathrm{n}}\right] \mathrm{A}_{2}+(\mathrm{n}+2) \mathrm{H}_{2} \mathrm{O}$

where $\mathrm{L}$ denotes the carriers molecule.

The reactions, described by equation (2) and involving a change in the coordination number, are typical for $\mathrm{Zn}(\mathrm{II}), \mathrm{Cd}(\mathrm{II}), \mathrm{Cu}(\mathrm{II})$ and $\mathrm{Co}(\mathrm{II})$, especially for the fourth stage of complexation $(n=4)^{5,9-11,20,22,26,27}$. In such cases, configuration equilibria are established (equation 3) between $\mathrm{ML}_{\mathrm{n}}$ complexes, which have different coordination sphere structures, for instance:

$\left[\mathrm{M}\left(\mathrm{H}_{2} \mathrm{O}\right)_{2} \mathrm{~L}_{4}\right]^{2+} \leftrightarrow\left[\mathrm{ML}_{4}\right]^{2+}+2 \mathrm{H}_{2} \mathrm{O}$

The occurrence of configuration equilibria in the n-th stage of complexation will lead to higher values of its corresponding stability constant, $\beta_{\mathrm{n}}$, because it is a sum of the stability constant of the tetrahedral complex, $\beta_{\mathrm{t}}$, and the octahedral complex $\beta_{\mathrm{o}}\left(\beta_{\mathrm{n}}=\beta_{\mathrm{t}}+\beta_{\mathrm{o}}\right)^{5,10,20,25}$.

Phenomena which change the structure and the values of stability constants of metal complexes may affect 
the process of competitive transport of metal cations through PIM ${ }^{14-16}$.

It was the objective of this paper to determine the consequences of the steric effect which occurs in imidazole carriers on the competitive transport of non-ferrous metal cations through PIM. To this end, the authors compared earlier reports comprising their findings, where 1-alkylimidazoles ${ }^{12}$, 13, 15, 1-alkyl-2-methylimidazoles ${ }^{14,} 16$ and 1-alkyl-4-methylimidazoles ${ }^{\mathbf{2 6}}$ were used as carriers of metal cations.

In this work, the authors present results of their investigation of the competitive transportation of the copper(II), zinc(II), cobalt(II) and nickel(II) ions across inclusion membranes containing 1-heptylimidazole (1), 1-heptyl2-methylimidazole (2), and 1-heptyl-4-methylimidazole (3) from chloride solutions.

The values of three parameters: initial flux $\left(\mathrm{J}_{\mathrm{i}}\right)$, selectivity coefficient $\left(\mathrm{S}_{(\mathrm{M}(1) / \mathrm{M}(2)}\right)$, and recovery factor of a given metal after 24 hours (RF) were selected for the comparative analysis of the transport process. Such comparison is feasible because all the studies on the competitive transport of metals have been carried out by these authors in same conditions, which are described in the Experimental part.

\section{EXPERIMENTAL}

\section{Reagents}

Inorganic chemicals: copper(II), zinc(II), cobalt(II) and nickel(II) chlorides or nitrates and tetramethylammonium hydroxide were of analytical grade and were purchased from POCh (Gliwice, Poland). Aqueous solutions were prepared with double distilled water (conductivity 5 $\mu \mathrm{S} / \mathrm{m}$ ). Organic reagents, i.e., cellulose triacetate (CTA), $o$-nitrophenyl pentyl ether (o-NPPE), and dichloromethane (all from Fluka) were of analytical grade and were

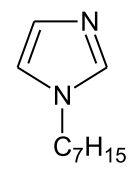
1

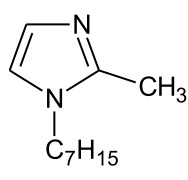
$\underline{2}$

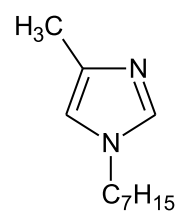

$\underline{\mathbf{3}}$
$\mathrm{pKa}=7.32[9]$

$$
\mathrm{pKa}=8.35[9]
$$$$
\mathrm{pKa}=8.01[9]
$$

Figure 2. Chemical structure of investigated alkylimidazoles

used without further purification. Alkylimidazoles $\underline{\mathbf{1}}-\underline{\mathbf{3}}$ (Fig. 2) were synthesized as described $\mathrm{in}^{27}$.

\section{Polymer inclusion membrane preparation}

The membranes were prepared according to the procedure reported in the previous $\operatorname{paper}^{28,29}$. A solution of cellulose triacetate, plasticizer, alkylimidazoles $(\underline{\mathbf{1}}-\underline{\mathbf{3}})$ as ion carriers in dichloromethane was prepared. A specified portion of the solution was poured into a membrane mould consisting of a $9.0 \mathrm{~cm}$ diameter glass ring fixed on a glass plate with cellulose triacetatedichloromethane glue. After evaporation of the solvent overnight the resulting membrane was peeled off from the glass plate by immersion in cold water. Then the membrane was soaked for 12 hours in distilled water to ensure its homogeneity. Two discs were cut out from the same preparation to duplicate transport experiments. The wet membrane contained $2.67 \mathrm{~cm}^{3} o$-NPPE $/ 1 \mathrm{~g}$ CTA, and $0.25-1.5 \mathrm{M}$ concentration of alkylimidazoles $(\underline{\mathbf{1}}-\underline{\mathbf{3}})$ based on plasticizer.

A surface characterization study of the polymer membranes was performed by atomic force microscopy (AFM) according to the procedure described in $\operatorname{paper}^{28}$. The analysis of surface pore characteristics was made using the AFM image processing program NanoScope v.5.12, which enabled the calculation of two parameters, roughness $\left(R_{q}\right)$ and porosity $(\varepsilon)$. Parameter $R_{q}$ is the standard deviation of the $z$ values within the box cursor and is calculated as:

$R_{q}=\sqrt{\frac{\sum\left(z_{i}\right)^{2}}{n}}$

where: $z_{i}$ - is the current $z$ value, $n-$ is the number of points within the box cursors.

\section{Transport studies}

Transport experiments were carried out in a permeation cell described in an earlier paper by the same authors ${ }^{\mathbf{2 8}, 29}$. The membrane film (surface area $4.9 \mathrm{~cm}^{2}$ ) was tightly clamped between two cell compartments. Both, the source and the receiving aqueous phases (45 $\mathrm{cm}^{3}$ each) were mechanically stirred at $600 \mathrm{rpm}$. Metal chlorides were used in the source phase whereas the receiving phase was deionized water. The concentration of each metal ions in the mixture was $c_{\mathrm{M}}=0.001 \mathrm{~mol} /$ $\mathrm{dm}^{3}$ The PIM transport experiments were carried out at $20 \pm 0.2^{\circ} \mathrm{C}$. Small samples of the aqueous receiving phase were taken periodically from the sampling port equipped with a syringe and analyzed by atomic absorption spectroscopy (AAS Spectrometer, Solar 939, Unicam) to determine zinc(II), cobalt(II), nickel(II), and copper(II) concentrations. The $\mathrm{pH}$ of the source phase (6.8) was kept constant using tetramethylammonium hydroxide.

The kinetics of the transport across the PIMs was described as a first-order process with respect to the metal-ion concentration ${ }^{30}$ expressed by equation (5):

$\ln \left(\frac{\mathrm{c}}{\mathrm{c}_{\mathrm{i}}}\right)=-\mathrm{kt}$

where $c$ is the metal ions concentration in the source phase at a given time $(\mathrm{M}), c_{i}$ is the initial metal ions concentration in the source phase, $k$ is the rate constant $\left(\mathrm{s}^{-1}\right)$, and $t$ is the time of transport $(\mathrm{s})$.

To calculate the value of $k, \ln \left(c / c_{i}\right)$ versus time was plotted. The rate constant values for two independent transport experiments were averaged and standard deviation was calculated. The correlation between $\ln \left(c / c_{i}\right)$ and time was linear, which was confirmed by the high correlation coefficient $\left(\mathrm{R}^{2}\right)$ ranging from 0.9621 to 0.9995 . The permeability coefficient $(P)$ was calculated according to equation (6):

$\mathrm{P}=-\frac{\mathrm{V}}{\mathrm{A}} \mathrm{k}$

where $V$ is the volume of the aqueous source phase $\left[\mathrm{m}^{3}\right]$, $k$ is the rate constant and $A$ is an effective area of the membrane $\left[\mathrm{m}^{2}\right]$.

The initial flux $\left(J_{i}\right)$ is equal to: 
$\mathrm{J}_{\mathrm{i}}=\mathrm{P} \cdot \mathrm{c}_{\mathrm{i}}$

The selectivity coefficient $(S)$ was defined as the ratio of initial fluxes for $\mathrm{M}_{1}$ and $\mathrm{M}_{2}$ metal ions, respectively: $\mathrm{S}=\mathrm{J}_{\mathrm{i}, \mathrm{M} 1} / \mathrm{J}_{\mathrm{i}, \mathrm{M} 2}$

To describe the efficiency of metal removal from the source phase, the recovery factor (RF) was calculated: $\mathrm{RF}=\frac{\mathrm{c}_{\mathrm{i}}-\mathrm{c}}{\mathrm{c}_{\mathrm{i}}} \cdot 100 \%$

The reported values correspond to the average values of three replicates, with the standard deviation within $5 \%$.

\section{RESULTS AND DISCUSSION}

As demonstrated in a number of papers ${ }^{12-16,26,28-31}$, selectivity of transport of the metal ions depends much on the physico-chemical characteristics of the polymeric inclusion membranes. As claimed in ${ }^{32,33}$, both the porosity and roughness of the membranes is determined by the kind and concentration of the ion carrier. Therefore, in the first step of this study, the synthesized polymeric inclusion membranes were subjected to microscopic examination. Figure 3 shows an atomic force microscopy (AMF) image of PIM with the carrier $\underline{\mathbf{3}}$ in a threedimensional form in the $1.0 \times 1.0 \mu \mathrm{m}^{2}$.

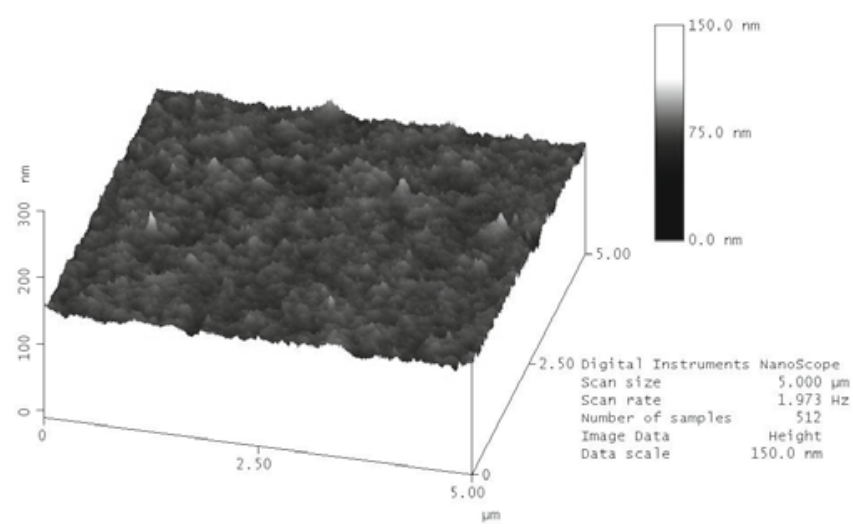

Figure 3. 3D-view atomic force microscopy (AFM) for PIM with 1-heptyl-4-methylimidazole $\underline{\mathbf{3}}$

The distribution of the carrier in the investigated membrane after evaporation of the dichloromethane is homogeneous on the entire surface. One of the membrane's features is well-defined pores. The pores are clearly visible as small well-defined dark areas. The pores on CTA matrix were filled with plasticizer (o-NPPE) and the 1-heptyl-4-methylimidazole (carrier). The imidazole carriers tend to crystallize in the membrane causing roughness and differentiated porosity.

In the Table 1 summarized an AFM characterization parameters for the polymeric inclusion membranes doped with 1-heptylimidazole (1), 1-heptyl-2-methylimidazole $(\underline{\mathbf{2}})$ and 1-heptyl-4-methylimidazole ( $\underline{\mathbf{3}})$ (the carrier). The degree of porosity of the investigated membrane is

Table 1. AFM characterization parameters for PIMs. Scan areas $1 \mu \mathrm{m}^{2}$

\begin{tabular}{|l|c|c|}
\hline Membrane & $\begin{array}{c}\text { Roughness }[R q], \\
{[\mathrm{nm}]}\end{array}$ & $\begin{array}{c}\text { Porosity }[\varepsilon], \\
{[\%]}\end{array}$ \\
\hline PIM with 1-heptylimidazole 1 & 3.9 & 21.1 \\
\hline $\begin{array}{l}\text { PIM with 1-heptyl-2- } \\
\text { methylimidazole 2 }\end{array}$ & 2.4 & 16.3 \\
\hline $\begin{array}{l}\text { PIM with 1-heptyl-4- } \\
\text { methylimidazole 3 }\end{array}$ & 2.7 & 18.9 \\
\hline
\end{tabular}

21.1, 16.3 and $18.9 \%$, respectively. The high roughness, which equals $3.9 \mathrm{~nm}$, was obtained for 1-heptylimidazole $(\underline{\mathbf{1}})$. The roughnesses of the membrane with carrier ( $\underline{\mathbf{2}})$ and (프) are equal to 2.4 and $2.7 \mathrm{~nm}$, respectively. It can be assumed that the decrease in the membrane's porosity is due to the increase in the molar volumes of the molecules of carriers $\underline{\mathbf{2}}$ and $\underline{\mathbf{3}}$ in connection with the presence of the methyl group in position 2 of their rings. The intrinsic molar volumes of carries $\underline{\mathbf{2}}$ and $\underline{\mathbf{3}}$ are $169.5 \mathrm{~mol} / \mathrm{cm}^{3}(\mathrm{HLB}=4.87)$, while for carrier $\underline{\mathbf{1}}$, it is $152.26 \mathrm{~mol} / \mathrm{cm}^{3}$ (HLB = 8.82). The roughness of investigated PIMs is comparable with that found for polymer membrane with derivative imidazole azothiacrown ethers prepared by Ulewicz et al. ${ }^{28}$, which is equal from 3.3 to $5.3 \mathrm{~nm}$. Also, small values of roughness (equal to $4.6 \mathrm{~nm}$ ) showed polymer membranes with D2EHPA prepared by Salazar-Alvarez et al. ${ }^{34}$.

Table 2. . Initial fluxes for competitive transport of $\mathrm{Cu}(\mathrm{II})$, $\mathrm{Zn}(\mathrm{II}), \mathrm{Co}(\mathrm{II})$, and $\mathrm{Ni}(\mathrm{II})$ ions across PIM doped with 1-heptyl-2-methylimidazole (2) and recovery factor after $24 \mathrm{~h}$; membrane: $2.6 \mathrm{~cm}^{3} o$-NPPE $/ 1 \mathrm{~g}$ CTA; source phase: $\left[\mathrm{Me}^{2+}\right]=0.001 \mathrm{M}$ each, receiving phase: deionized water, $\mathrm{pH}=6.8$.

\begin{tabular}{|l|c|c|c|}
\hline $\begin{array}{l}\text { Concentration of } \\
\text { carrier, [M] }\end{array}$ & Metal ions & $\begin{array}{c}\text { Initial flux, } \\
\mathrm{J}_{\mathrm{i}} \\
\mu \mathrm{mol} / \mathrm{m}^{2} \cdot \mathrm{s}\end{array}$ & $\begin{array}{c}\mathrm{RF} \text { after } \\
24 \mathrm{~h},[\%]\end{array}$ \\
\hline \multirow{4}{*}{0.25} & $\mathrm{Cu}(\mathrm{II})$ & 0.50 & 37.8 \\
\cline { 2 - 4 } & $\mathrm{Zn}(\mathrm{II})$ & 0.05 & 5.2 \\
\cline { 2 - 4 } & $\mathrm{Co}(\mathrm{II})$ & 0.02 & 2.7 \\
\cline { 2 - 4 } & $\mathrm{Ni}(\mathrm{II})$ & 0.02 & 1.65 \\
\hline \multirow{5}{*}{0.50} & $\mathrm{Cu}(\mathrm{II})$ & 1.98 & 84.9 \\
\cline { 2 - 4 } & $\mathrm{Zn}(\mathrm{II})$ & 0.25 & 18.2 \\
\cline { 2 - 4 } & $\mathrm{Co}(\mathrm{II})$ & 0.08 & 9.4 \\
\cline { 2 - 4 } & $\mathrm{Ni}(\mathrm{II})$ & 0.02 & 2.13 \\
\hline \multirow{5}{*}{1.0} & $\mathrm{Cu}(\mathrm{II})$ & 3.86 & 97.2 \\
\cline { 2 - 4 } & $\mathrm{Zn}(\mathrm{II})$ & 1.10 & 63.1 \\
\cline { 2 - 4 } & $\mathrm{Co}(\mathrm{II})$ & 0.40 & 34.8 \\
\cline { 2 - 4 } & $\mathrm{Ni}(\mathrm{II})$ & 0.31 & 22.6 \\
\hline \multirow{5}{*}{1.5} & $\mathrm{Cu}(\mathrm{II})$ & 3.41 & 96.8 \\
\cline { 2 - 4 } & $\mathrm{Zn}(\mathrm{II})$ & 1.26 & 67.1 \\
\cline { 2 - 4 } & $\mathrm{Co}(\mathrm{II})$ & 0.53 & 39.6 \\
\cline { 2 - 4 } & $\mathrm{Ni}(\mathrm{II})$ & 0.44 & 28.5 \\
\hline
\end{tabular}

In preliminary experiments, no metal ion transport across a liquid membrane containing only the support (CTA) and plasticizer (o-NPPE), i.e., in the absence of an ion carrier was observed. Then, the influence of the carrier concentration in the membrane on separation efficiency of the $\mathrm{Cu}(\mathrm{II}), \mathrm{Zn}(\mathrm{II}), \mathrm{Co}(\mathrm{II})$, and $\mathrm{Ni}(\mathrm{II})$ ions from their equimolar mixture was determined.

The values of initial fluxes for competitive transport of $\mathrm{Cu}(\mathrm{II}), \mathrm{Zn}(\mathrm{II}), \mathrm{Co}(\mathrm{II})$, and $\mathrm{Ni}(\mathrm{II})$ across PIM vs. concentration of 1-heptyl-2-methylimidazole $(\underline{\mathbf{2}})$ in the polymer inclusion membrane are shown in Table 2 .

The fluxes of all the metal ions rapidly increase with the increase of ionophore concentration in the membrane up to a $1.0 \mathrm{M}$ calculation on the plasticizer's volume. The highest initial fluxes of $\mathrm{Cu}(\mathrm{II})$ are found at the 1.0 $\mathrm{M}$ concentration. Above this concentration, the rate of $\mathrm{Cu}$ (II) ion transport is slightly lower but for the remaining three cations the initial flux increases, especially 
for $\mathrm{Co}(\mathrm{II})$ which forms two types of complexes at higher concentrations of the carrier (ligand) (eq. 10).

$$
\begin{aligned}
& {\left[\mathrm{Co}\left(\mathrm{H}_{2} \mathrm{O}\right)_{6}\right]^{2+}+4 \mathrm{~L}+2 \mathrm{~A}^{-} \leftrightarrow\left[\mathrm{M}\left(\mathrm{H}_{2} \mathrm{O}\right)_{2} \mathrm{~L}_{4}\right] \mathrm{A}_{2}+4 \mathrm{H}_{2} \mathrm{O}} \\
& {\left[\mathrm{Co}\left(\mathrm{H}_{2} \mathrm{O}\right)_{6}\right]^{2+}+4 \mathrm{~L}+2 \mathrm{~A}^{-} \leftrightarrow\left[\mathrm{ML}_{4}\right] \mathrm{A}_{2}+6 \mathrm{H}_{2} \mathrm{O}}
\end{aligned}
$$

In the next experiment, the transport of $\mathrm{Cu}(\mathrm{II}), \mathrm{Zn}(\mathrm{II})$, $\mathrm{Co}(\mathrm{II})$, and $\mathrm{Ni}$ (II) ions into the receiving deionized water across a PIM doped with carriers $\underline{\mathbf{1}}-\underline{\mathbf{3}}$ was carried out. The experimental results are summarized in Table 3.

The presence of the $-\mathrm{CH}_{3}$ group in position 2 of the imidazole ring in carrier molecules decreases the initial flux $\left(J_{i}\right)$ values compared with carrier $\underline{1}$ of which the molecule does not comprise a group creating a steric hindrance to combining with metal ions.

Different values of separation coefficients were obtained, depending on the carrier used. Introduction of a methyl group in position 2 or 4 of the imidazole ring (carrier $\underline{\mathbf{2}}$ and $\underline{\mathbf{3}}$ ) leads to much lower separation coefficients. Compared with carrier $\underline{\mathbf{1}}$, carrier $\underline{\mathbf{2}}$, and carrier $\underline{\mathbf{3}}$ does not differentiate the transport between the ions $\mathrm{Co}(\mathrm{II})$ and $\mathrm{Ni}(\mathrm{II})$.

A more pronounced effect on the differences in transport was observed for carrier $\underline{\mathbf{3}}$, where the $-\mathrm{CH}_{3}$ group is in position 4 if the imidazole ring: it produced the highest values of separation coefficients. For the separation of $\mathrm{Zn}(\mathrm{II}) / \mathrm{Cd}(\mathrm{II}), \mathrm{ZnCd}(\mathrm{II}) / \mathrm{Co}(\mathrm{II})$ and $\mathrm{ZnCo}(\mathrm{II}) /$ $\mathrm{Ni}(\mathrm{II})$, they are 11.6, 24.8 and 33.8, respectively. The rate of metal ion transfer across polymer membranes containing imidazole derivatives decreases in the order: $\underline{\mathbf{1}}>\underline{\mathbf{3}}>\underline{\mathbf{2}}$. The highest rates of metal ion transfer were observed for the membranes, containing carrier (1): they were characterized by the highest porosity $(21.1 \%)$ and roughness $(3.9 \mathrm{~nm})$.
There was a decrease in the stability of all the metal complexes due to steric hindrance, which in turn, depends on the kind of the central ion (Table 4).

As seen in Table 4 the stability constants for 1-heptylimidazole complexes with all metal ions are the highest. Stability constants of the $\mathrm{Cu}$ (II) complexes are considerably higher than those of $\mathrm{Co}(\mathrm{II}), \mathrm{Ni}(\mathrm{II})$, and $\mathrm{Zn}$ (II). This may be explained in terms of a larger contribution of the $\mathrm{p}_{\mathrm{M} \otimes \mathrm{L}}$ back donation to interaction of $\mathrm{Cu}$ (II) with the imidazole ring $^{5,7}$.

A steric effect, caused by the presence of the $-\mathrm{CH}_{3}$ group in the position 2 of the imidazole ring, is observed to increase selectivity coefficients for $\mathrm{Cu}$ (II) in respect of $\mathrm{Ni}(\mathrm{II})$, though only in the case of carriers $\underline{\mathbf{1}}$ and $\underline{\mathbf{2}}$.

The $\mathrm{Cu}(\mathrm{II})$ ions were transported across PIMs doped both with $\underline{\mathbf{1}}$ and $\underline{\mathbf{2}}$ most effectively from the mixtures. $\mathrm{Cu}$ (II) ions are much less sensitive to the steric effect, because the coordination sphere of $\mathrm{Cu}$ (II) is much more flexible, i.e., more readily deformable ${ }^{5,7,11,23,38}$. The $\mathrm{Cu}$ (II) ion can also form 4-coordination complexes ${ }^{11,21-23}$. Both the enhanced basicity and the steric hindrance in the molecule of carrier $\underline{\mathbf{2}}$ and $\underline{\mathbf{3}}$ slows down the rate of transport of the $\mathrm{Cu}(\mathrm{II}), \mathrm{Zn}$ (II) and $\mathrm{Co}(\mathrm{II})$ ions, in spite of the fact that the ions can form both the 6- and 4-coordinate species (eq. 2), and in both forms can be transported across the membrane.

The Ni(II) ions are devoid of this capability and for this reason are only slightly transported across the membranes.

Figure 4 shows the dependence the recovery factor (RF) of the metal ions from the feeding phase after $24 \mathrm{hrs}$ during the transport across the 1-heptylimida-

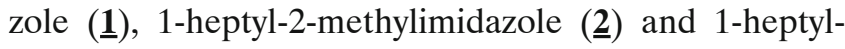
4-methylimidazole (프) doped PIM.

Table 3. Initial fluxes, selectivity order and selectivity coefficients for competitive transport of $\mathrm{Cu}(\mathrm{II}), \mathrm{Zn}(\mathrm{II}), \mathrm{Co}(\mathrm{II})$, and $\mathrm{Ni}$ (II)

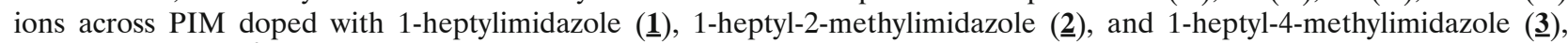

\begin{tabular}{|c|c|c|c|}
\hline Carrier & Metal ions & $\mathrm{J}_{\mathrm{i}}, \mu \mathrm{mol} / \mathrm{m}^{2} \cdot \mathrm{s}$ & $\mathrm{S}_{\mathrm{Cu}(I I) / \mathrm{Me}(I I)}$ \\
\hline \multirow{4}{*}{1} & $\mathrm{Cu}(\mathrm{II})$ & 3.68 & \multirow{4}{*}{$\begin{array}{ccc}\mathrm{Cu}(\mathrm{II})>\mathrm{Zn}(\mathrm{II})>\mathrm{Co}(\mathrm{II})>\mathrm{Ni}(\mathrm{II}) \\
3.7 \quad 17.8 \quad 35.7\end{array}$} \\
\hline & $\mathrm{Zn}(\mathrm{II})$ & 1.10 & \\
\hline & $\mathrm{Co}$ (II) & 0.40 & \\
\hline & $\mathrm{Ni}(\mathrm{II})$ & 0.31 & \\
\hline \multirow{4}{*}{$\underline{2}$} & $\mathrm{Cu}(\mathrm{II})$ & 2.27 & \multirow{4}{*}{$\begin{array}{cc}\mathrm{Cu}(\mathrm{II})>\mathrm{Zn}(\mathrm{II})>\mathrm{Co}(\mathrm{II}), \mathrm{Ni}(\mathrm{II}) \\
3.1 & 15.1\end{array}$} \\
\hline & $\mathrm{Zn}(\mathrm{II})$ & 0.73 & \\
\hline & $\mathrm{Co}(\mathrm{II})$ & 0.15 & \\
\hline & $\mathrm{Ni}(\mathrm{II})$ & 0.15 & \\
\hline \multirow{4}{*}{$\underline{3}$} & $\mathrm{Cu}(\mathrm{II})$ & 2.43 & \multirow{4}{*}{$\begin{array}{ccc}\mathrm{Cu}(\mathrm{II})>\mathrm{Zn}(\mathrm{II})>\mathrm{Ni}(\mathrm{II})>\mathrm{Co}(\mathrm{II}) \\
2.8 & 11.6 & 12.8\end{array}$} \\
\hline & $\mathrm{Zn}(\mathrm{II})$ & 0.87 & \\
\hline & $\mathrm{Co}(\mathrm{II})$ & 0.19 & \\
\hline & $\mathrm{Ni}(\mathrm{II})$ & 0.21 & \\
\hline
\end{tabular}
membrane: $2.6 \mathrm{~cm}^{3} o$-NPPE $/ 1 \mathrm{~g}$ CTA and $1.0 \mathrm{M}$ carriers calculated on plasticizer

Table 4. Comparison of the stability constants $\beta \mathrm{n}$ of $\mathrm{Co}(\mathrm{II}), \mathrm{Ni}(\mathrm{II}), \mathrm{Cu}(\mathrm{II})$, and $\mathrm{Zn}(\mathrm{II})$ complexes with 1-heptylimidazole (1)

\begin{tabular}{|c|c|c|c|c|c|}
\hline Ligand & Metal ions & $\log \beta_{1}$ & $\log \beta_{2}$ & $\log \beta_{3}$ & $\log \beta_{4}$ \\
\hline \multirow{3}{*}{1} & $\mathrm{Co}(\mathrm{II})[36]$ & 3.47 & 5.64 & 7.14 & 8.38 \\
\hline & $\mathrm{Cu}(\mathrm{II})[7]$ & 4.15 & 7.57 & & \\
\hline & $\mathrm{Zn}(\mathrm{II})[37]$ & 3.36 & 5.87 & 8.07 & \\
\hline \multirow{4}{*}{$\underline{2}$} & $\mathrm{Co}(\mathrm{II})$ [35] & 1.96 & 2.18 & 3.02 & 5.61 \\
\hline & $\mathrm{Cu}(\mathrm{II})$ [11] & 3.52 & 6.63 & 8.98 & \\
\hline & $\mathrm{Zn}(\mathrm{II})[10]$ & 3.48 & 5.80 & 8.30 & 10.10 \\
\hline & $\mathrm{Ni}(\mathrm{II})[5]$ & 2.08 & 4.62 & & \\
\hline \multirow{4}{*}{$\underline{3}$} & $\mathrm{Co}(\mathrm{II})$ [25] & 1.40 & 2.04 & 3.02 & 5.61 \\
\hline & $\mathrm{Cu}(\mathrm{II})[21]$ & 3.72 & 4.55 & 6.53 & \\
\hline & $\mathrm{Zn}(\mathrm{II})[20]$ & 2.95 & 5.60 & 6.30 & \\
\hline & $\mathrm{Ni}(\mathrm{II})$ [25] & 1.74 & 3.00 & 3.92 & \\
\hline
\end{tabular}
1-heptyl-2-methylimidazole $(\underline{\mathbf{2}})$, and 1-heptyl-4-methylimidazole $(\underline{\mathbf{3}})$ at $25^{\circ} \mathrm{C}$, ionic strength $0.5 \mathrm{~mol} / \mathrm{dm}^{3}\left(\mathrm{KNO}_{3}\right)$ 


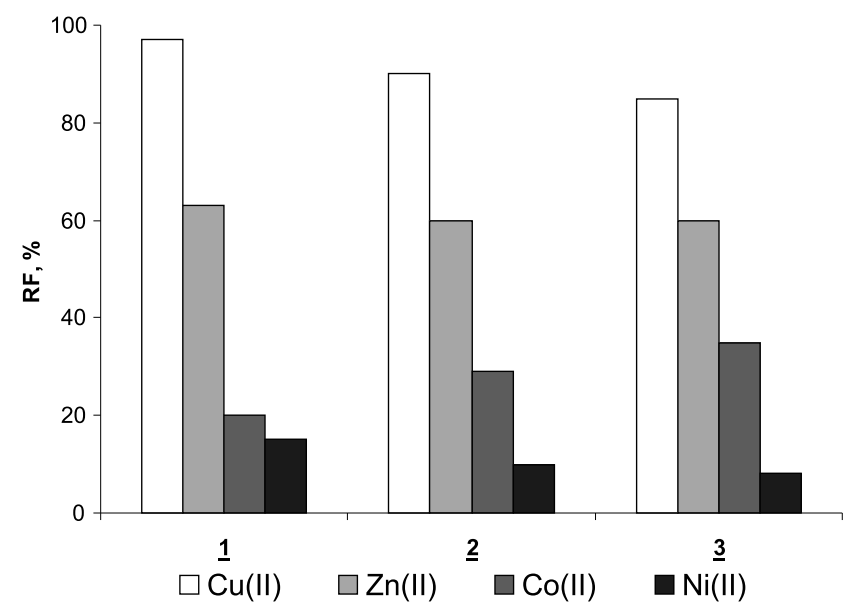

Figure 4. Recovery factor of the metal ions from the feeding phase after 24 hrs during the transport across PIM doped with 1-heptylimidazole (1), 1-heptyl-2-methylimidazole ()ㅡ, and 1-heptyl-4-methylimidazole ( $\underline{\mathbf{3}})$

The highest recovery values were obtained for $\mathrm{Cu}(\mathrm{II})$, this being 99 and $85 \%$ for carrier $\underline{\mathbf{1}}$ and $\underline{\mathbf{2}}$, respectively. In all membranes the degree of deposition of the $\mathrm{Zn}(\mathrm{II})$ ions was comparable ( $\mathrm{ca}$ 60\%). In the case of $\mathrm{Co}(\mathrm{II})$, the deposition for carrier $\underline{\mathbf{2}}$ and $\underline{\mathbf{3}}$ was by $10 \%$ and $15 \%$, respectively higher than that for carrier $\underline{\mathbf{1}}$.

The steric effect of the carrier hinders the transport of $\mathrm{Ni}(\mathrm{II})$ ions. The values of $\mathrm{RF}$ for $\mathrm{Ni}(\mathrm{II})$ ions, decreasing in the order: $\underline{\mathbf{1}}>\underline{\mathbf{2}}>\underline{\mathbf{3}}$, are 15,10 and $8 \%$, respectively.

\section{CONCLUSION}

The values of initial flux and recovery factors depend on the type of carrier used. The steric effect for carriers $\underline{\mathbf{2}}$ and $\underline{\mathbf{3}}$ decreases the transport of all ions except $\mathrm{Cu}(\mathrm{II})$, since they are characterized by plasticity of their coordination sphere and are resistant to a steric hindrance resulting from the carrier's structure.

The initial fluxes of metal ions transport across PIMs with the $\underline{\mathbf{1}}-\underline{\mathbf{2}}$ decrease in the sequence: $\mathrm{Cu}(\mathrm{II})>\mathrm{Zn}(\mathrm{II})$ $>\mathrm{Co}(\mathrm{II})>\mathrm{Ni}(\mathrm{II})$, whereas for $\underline{\mathbf{3}}$ they were $\mathrm{Cu}(\mathrm{II})>$ $\mathrm{Zn}(\mathrm{II})>\mathrm{Ni}(\mathrm{II})>\mathrm{Co}(\mathrm{II})$. The highest recovery values were obtained for $\mathrm{Cu}(\mathrm{II})$, this being 99 and $85 \%$ for carrier $\underline{\mathbf{1}}$ and $\underline{\mathbf{2}}$, respectively. In both membranes the degree of deposition of the $\mathrm{Zn}(\mathrm{II})$ ions was comparable (ca 60\%).

$\mathrm{Zn}$ (II) and $\mathrm{Co}(\mathrm{II})$ ions, which form complexes with coordination number 4 and 6 , are more easily recovered with the use of carriers $\underline{\mathbf{2}}$ and $\underline{\mathbf{3}}$.

$\mathrm{Ni}(\mathrm{II})$ ions, which form complexes with coordination number 6 only, practically remain in the feeding phase. Their transport is low and decreases in the order: $\underline{\mathbf{1}}>$ $\underline{\mathbf{3}}>\underline{\mathbf{2}}$.

\section{LITERATURE CITED}

1. Almeida, M.I.G.S., Cattrall, R.W. \& Kolev, S.D. (2012). Recent trends in extraction and transport of metal ions using polymer inclusion membranes (PIMs). J. Membr. Sci. 415-416, 9-23. DOI: dx.doi.org/10.1016/j.memsci.2012.06.006.

2. Nghiem, L.D., Mornane, P., Potter, I.D., Perera, J.M., Cattrall, R.W. \& Kolev, S.D. (2006). Extraction and transport of metal ions and small organic compounds using polymer inclusion membranes (PIMs). J. Membr. Sci. 281, 7-41. DOI: dx.doi.org/10.1016/j.memsci.2006.03.035.
3. Abdul-Halima, N.S., Whittenb, P.G. \& Nghiema, L.D. (2013). Characterizing poly (vinyl chloride)/Aliquat 336 polymer inclusion membranes: Evidence of phase separation and its role in metal extraction. Sep. Purif. Technol. 119, 14-18. DOI: dx.doi.org/10.1016/j.seppur.2013.08.038.

4. Sgarlata, C., Arena, G., Longo, E., Zhang, D., Yang, Y. \& Bartsch, R.A. (2008). Heavy metal separation with polymer inclusion membranes. J. Membr. Sci. 323, 444-451. DOI: dx.doi. org/10.1016/j.memsci.2008.07.004.

5. Radzymińska-Lenarcik, E. (2008). Search for the possibility of utilizing the differences in complex-forming capacities of alkylimidazoles for selective extraction of some metal ions from aqueous solutions. Pol. J. Chem. Technol. 10, 73-78. DOI: 10.2478/v10026-008-0017-3.

6. Lenarcik, B. \& Rauckyte, T. (2004). The influence of alkyl length on extraction equilibria of $\mathrm{Ni}$ (II) complexes with 1-alkylimidazoles in aqueous solution/organic solvent systems. Sep. Sci. Technol. 39, 3353-3372. DOI: 10.1081/SS-200028915. 7. Radzymińska-Lenarcik, E. (2007). The influence of the alkyl chain length on extraction equlibrium of $\mathrm{Cu}$ (II) complexes with 1-alkylimidazoles in aqueous solution/ organic solvent systems,. Solv. Extr. Ion Exch. 25, 53-64. DOI:10.1080/07366290601067572. 8. Gheaedi, M., Niknam, K., Shokrollahi, A., Niknam, E., Gheadi, H. \& Soylak, M. (2008). A solid extraction procedure for $\mathrm{Fe} 3+, \mathrm{Cu} 2+$ and $\mathrm{Zn} 2+$ ions on 2-phenyl-1H-benzo[d] imidazole loaded on Triton Z-100 coated polyvinyl chloride. J. Hazard. Mat. 158, 131-136. DOI: dx.doi.org/10.1016/j.jhazmat.2008.01.037.

9. Lenarcik, B., Adach, A. \& Radzyminska-Lenarcik, E. (1999). The influence of steric effect and alkyl chain length on the extraction of the complexes of $\mathrm{Co}(\mathrm{II}), \mathrm{Ni}(\mathrm{II}), \mathrm{Cu}(\mathrm{II}), \mathrm{Zn}(\mathrm{II})$, and $\mathrm{Cd}(\mathrm{II})$ with 1-alkyl-2-methylimidazole. Pol. J. Chem. 73, $1273-1281$

10. Lenarcik, B. \& Kierzkowska, A. (2006). The influence of alkyl chain length and steric effect on extraction of zinc(II) complexes with 1-Alkyl-2-methylimidazoles. Solv. Extr. Ion Exch. 24, 433-445. DOI: 10.1080/07366290600646962.

11. Radzymińska-Lenarcik, E. (2007). Effect of alkyl chain length on the extraction of copper(II) complexes with 1-alkyl2-methylimidazoles. Sep. Sci. Technol. 42, 2661-2675. DOI: 10.1080/01496390701515003.

12. Ulewicz, M. \& Radzyminska-Lenarcik, E. (2011). Transport of metal ions across polymer inclusion membrane with 1-alkylimidazole. Phys. Probl. Miner. Process. 46, 199-130.

13. Radzyminska-Lenarcik, E. \& Ulewicz, M. (2012). Selective transport of $\mathrm{Cu}(\mathrm{II})$ across a polymer inclusion membrane with 1-alkylimidazole from nitrate solutions. Sep. Sci. Technol. 47, 1113-1118. DOI:10.1080/01496395.2011.646378.

14. Ulewicz, M. \& Radzyminska-Lenarcik, E. (2012). Supported liquid (SLM) and polymer inclusion (PIM) membranes pertraction of copper(II) from aqueous nitrate solutions by 1-hexyl-2-methylimidazole. Sep. Sci. Technol. 47, 1383-1389. DOI: $10.1080 / 01496395.2012 .672523$.

15. Radzyminska-Lenarcik, E. \& Ulewicz, M. (2014). The use of 1-alkylimidazoles for selective separation of zinc ions in the transport process across a polymeric inclusion membrane. Phys. Probl. Miner. Process. 50, 131-142. DOI: 10.5277/ppmp140112. 16. Ulewicz, M. \& Radzyminska-Lenarcik, E. (2012). Application of supported and polymer membrane with 1-decyl2-methylimidazole for separation of transition metal ions. Phys. Probl. Miner. Process. 48, 91-102.

17. Sundberg, R.J. \& Martin, R.B. (1974). Interactions of Histidine and other Imidazole Derivatives with Transition Metal Ions in Chemical and Biological System. Chem. Rev. 74, 471-517. DOI: dx.doi.org/10.1155\%2F2007\%2F96536.

18. Pearson, R.G. (1968). Hard and Soft Acids and Bases, HSAB, Part I. Fundamental principles. J. Chem. Edu. 45, 581-586. DOI: dx.doi.org/10.1021\% 2Fed045p581.

19. Lenarcik, B. \& Ojczenasz, P. (2002). The influence of the size and position of the alkyl groups in alkylimidazole mol- 
ecules on their acid - base properties. J. Heterocycl. Chem. 39, 287-290. DOI: 10.1080/07366290601067572.

20. Lenarcik, B. \& Kierzkowska, A. (2004). The Influence of Alkyl Chain Length and Steric Effect on Stability Constants and Extractability of $\mathrm{Zn}$ (II) Complexes with 1-Alkyl-4-methylimidazoles. Sep. Sci. Technol. 39, 3485-3508. DOI: 10.1081/ SS-200033148.

21. Radzyminska-Lenarcik, E. (2010). The influence of steric effect, alkyl chain length and donor number of solvents on the ex-traction of copper(II) complexes with 1-alkyl4-methylimidazoles. Solv. Ext. Ion Exch. 28, 636-652. DOI: 10.1080/07366299.2010.499292.

22. Radzyminska-Lenarcik, E. (2008). Influence of the steric hindrance, ligand hydrophobicity and DN of solvents on structure and extraction of $\mathrm{Cu}(\mathrm{II})$ complexes of 1-alkyl-2-ethylimidazoles. Sep. Sci. Technol. 43, 794-814. DOI: 10.1080/01496390701870655.

23. Radzyminska-Lenarcik, E. (2009). The influence of alkyl chain length in 1,2-dialkylimidazoles on the extraction capacity and structure of their copper(II) complexes. Sep. Sci. Technol. 44, 954-970. DOI: 10.1080/01496390802437255.

24. Lenarcik, B. \& Barszcz, B. (1980). Stability and Structure of Transition Metal Complexes with Azoles in Aqueous Solutions. Part XXI. A Comparison of Complex-Forming of 1,2-Dimethylimidazole with that of Other 1,3-Diazoles. J. Chem. Soc. Dalton Trans. 24-28. DOI: 10.1039/DT9800000024.

25. Lenarcik, B., Kurdziel, K. \& Czopek, R. (1986). Search for optimum conditions of extraction of metal complexes with alkylimidazoles. III. Structure-extractability relationships for 1,4-dimethylimidazole complexes of $\mathrm{Co}(\mathrm{II}), \mathrm{Ni}(\mathrm{II})$, $\mathrm{Cu}(\mathrm{II}), \mathrm{Zn}(\mathrm{II})$, and $\mathrm{Cd}(\mathrm{II})$. Solv. Ext. Ion Exch. 4, 165-182. DOI: $10.1080 / 07366298608917860$.

26. Ulewicz, M. \& Radzyminska-Lenarcik, E. (2014). Application of polymer and supported membranes with 1-decyl-4-methylimidazole for pertraction of transition metal ions. Sep. Sci. Technol. 49, 1713-1721. DOI: 10.1080/01496395.2014.906453. 27. Pernak, J., Krysinski, J. \& Skrzypczak, A. (1987). Bakterizide Wirkung von Iminiumverbindungen, $A$. Tenside Surfact. Det. 24, 276-286.

28. Ulewicz, M., Szczygelska-Tao, J. \& Biernat, J.F. (2009). Selectivity of $\mathrm{Pb}(\mathrm{II})$ transport across polymer inclusion membranes doped with imidazole azothiacrown ethers. J. Membr. Sci. 344, 32-38. DOI: dx.doi.org/10.1016/j.memsci.2009.07.031. 29. Ulewicz, M., Sadowska, K. \& Biernat, J.F. (2007). Facilitated transport of $\mathrm{Zn}(\mathrm{II}), \mathrm{Cd}(\mathrm{II})$ and $\mathrm{Pb}(\mathrm{II})$ across polymer inclusion membrane doped with imidazole azocrown ethers. Desal. 214, 352-364. DOI: dx.doi.org/10.1016/j.desal.2006.12.006.

30. Ajji, Z. \& Ali, A.M. (2010). Separation of copper ions from iron ions using PVA-g-(acrylic acid/N-vinyl imidazole) membranes prepared by radiation-induced grafting. J. Hazard. Mat. 173, 71-74. DOI: dx.doi.org/10.1016/j.jhazmat.2009.08.049. 31. Ulewicz, M., Sadowska, K. \& Biernat, J.F. (2007). Selective transport of $\mathrm{Pb}(\mathrm{II})$ across polymer inclusion membrane using imidazole azocrown ethers as carriers. Phys. Probl. Miner. Process. 41, 133-143.

32. Danesi, P.R. (1984-85). Separation of metal species by supported liquid membranes. Sep. Sci. Technol. 19, 857-894. DOI: 10.1080/01496398408068598.

33. Visser, H.C., Reinhoudt, D.N. \& de Jong, F. (1994). Carriermediated transport through liquid membranes. Chem. Soc. Rev. 23, 75-81. DOI: 10.1039/CS9942300075.

34. Salazar-Alvarez, G., Bautista-Flores, A.N., San Miguel, E.R., Muhammed, M. \& Gyves, J. (2005). Transport characterization of a PIM system used for the extraction of $\mathrm{Pb}(\mathrm{II})$ using D2EHPA as carrier. J. Membr. Sci. 250, 247-257. DOI: 10.1016/j.memsci.2004.09.048.

35. Radzyminska-Lenarcik, E., \& Witt, K. (2015). The influence of alkyl chain length and steric effect on stability constants and extractability of $\mathrm{Co}(\mathrm{II})$ complexes with 1-alkyl-2-methyl- imidazoles. Sep. Sci. Technol., 50, 676-682. DOI: 10.1080/014 96395.2014.959600.

36. Lenarcik, B. \& Ojczenasz, P. (2004). Investigation of the stability constants of $\mathrm{Co}(\mathrm{II})$ complexes with a homologous series of 1-alkylimidazoles in aqueous solution by using a partition method with several solvents. Sep. Sci. Technol., 39, 199-226. DOI: $10.1081 /$ SS-120027409.

37. Lenarcik, B. \& Kierzkowska, A. (2004). The influence of alkyl length on stability constants of $\mathrm{Zn}$ (II) complexes with 1-alkylimidazoles in aqueous solutions and their partition between aqueous phase and organic solvent. Solv. Ext. Ion Exch. 22, 449-471. DOI: 10.1081/SEI-120030398.

38. Gâzo, J., Bersuker, I.B., Garaj, J., Kabešová, M., Kohout, J., Langfelderowá, H., Melník, M., Serator, M. \& Valach, F. (1976). Plasticity of the coordination sphere of Copper(II) complexes, its manifestation and causes. Coord. Chem. Rev. 19, 253-297. DOI: dx.doi.org/10.1016/S0010-8545(00)80317-3. 